\title{
Perbedaan Rerata Kadar Hemoglobin dan Feritin Berdasarkan Tingkat Inteligensia Anak di Sekolah Luar Biasa Kota Padang
}

\author{
Inggrit Anggraini, ${ }^{*}$ Eva Chundrayetti, ${ }^{*}$ Ellyza Nasrul** \\ *Departemen Ilmu Kesehatan Anak Fakultas kedokteran Universitas Andalas/ RSUP Dr.M. Djamil Padang, ${ }^{* *}$ Pascasarjana Ilmu \\ Biomedik Fakultas Kedokteran Universitas Andalas
}

Latar belakang. Fungsi intelektual dibawah rata-rata $(\mathrm{IQ}<70)$ yang muncul bersamaan dengan defisit perilaku adaptif dan bermanifestasi pada periode perkembangan disebut retardasi mental (RM). Defisiensi besi merupakan salah satu defisiensi nutrisi yang diduga menjadi etiologi RM.

Tujuan. Menilai perbedaan rerata kadar hemoglobin dan feritin berdasarkan tingkat inteligensia anak di Sekolah Luar Biasa Kota Padang. Metode. Penelitian cross sectional comparative pada November 2016 - Mei 2017 di Sekolah Luar Biasa (SLB) kota Padang. Sampel adalah siswa kelas C (tuna grahita) berusia 6-18 tahun. Sampel dikelompokkan berdasarkan tingkat intelligence quotient (IQ). Digunakan metode The Wechsler Intelligence Scale for Children $4^{\text {th }}$ edition (WISC-IV) dan dibagi 3 kelompok, yaitu kelompok tidak RM, RM ringan, dan RM sedang berat. Dilakukan pemeriksaan kadar hemoglobin dan kadar feritin semua kelompok sampel.

Hasil. Dari 60 anak di SLB Kota Padang, terdiri dari 20 anak di tiap kelompok. Jenis kelamin terbanyak adalah laki-laki (55\%) dan usia rata-rata 12,96 tahun. Median kadar ferritin kelompok RM sedang berat lebih rendah $(12,24(2,59-39,87) \mathrm{ng} / \mathrm{mL}) \mathrm{dibandingkan}$ kelompok tidak RM $(63,03(20,29-484,37) \mathrm{ng} / \mathrm{mL})$ dan RM ringan $(66,8(18,19-163,22) \mathrm{ng} / \mathrm{mL})$. Secara statistik terdapat perbedaan yang bermakna kadar hemoglobin dan feritin pada ketiga kelompok berdasarkan tingkat inteligensia $(\mathrm{p}<0,05)$.

Kesimpulan. Terdapat perbedaan rerata kadar hemoglobin dan feritin berdasarkan tingkat inteligensia anak di Sekolah Luar Biasa Kota Padang. Sari Pediatri 2018;20(4):207-13

Kata kunci: defisiensi besi, feritin, retardasi mental, tingkat inteligensia, SLB

\section{The Mean Difference of Haemoglobin and Ferritin Level Based on Child Intelligence Level at Special School of Padang}

Inggrit Anggraini, ${ }^{*}$ Eva Chundrayetti, ${ }^{*}$ Ellyza Nasrul**

Background. The below-average intellectual function (IQ <70) that coincides with the adaptive behavior deficit and manifests in the development period is referred to mental retardation (MR). Iron deficiency is one of the nutritional deficiencies suspected to be the etiology of MR.

Objective. To determine the mean difference of haemoglobin and ferritin level based on child intelligence level at Special School of Padang.

Methods. A comparative cross-sectional study to class C students (tuna grahita) aged 6-18 years old in Special Schools in Padang, conducted on November 2016 - May 2017. Sample's grouping based on the level of intelligence (IQ) examined using the Wechsler Intelligence Scale for Children 4th edition (WISC-IV) method into 3 groups ie no MR, mild MR, and moderate-severe MR. Haemoglobin and ferritin level were examined against all groups.

Result. About 60 children in Special school in Padang consisting of 20 children in each group. The most gender was male (55\%) and the mean age was 12.96 years old. The median of ferritin level in the moderate-severe MR group $(12,24(2,59-39,87) \mathrm{ng} / \mathrm{mL}) \mathrm{was}$ lower compared to the non MR group $(63,03(20,29-484,37) \mathrm{ng} / \mathrm{mL})$ and mild MR group $(66,8(18,19-163,22) \mathrm{ng} / \mathrm{mL})$. Statistically there was a significant difference in ferritin levels in all three groups based on intelligence levels.

Conclusions. There were the differences of haemoglobin and ferritin levelbased on the level of child intelligence. Sari Pediatri 2018;20(4):207-13

Keyword: iron deficiency, ferritin, mental retardation, intelligence level

Alamat korespondensi: Inggrit Anggraini. Departemen Ilmu Kesehatan Anak Fakultas Kedokteran Universitas Anadalas/RSUP dr. M. Djamil Jl. Perintis Kemerdekaan. Padang, Sumatera Barat. Email: inggrit_06@yahoo.com 
Inggrit Anggraini dkk: Perbedaan rerata kadar hemoglobin dan feritin berdasarkan tingkat inteligensia

$\mathrm{R}$ etardasi mental adalah fungsi intelektual dibawah rata-rata yang muncul bersamaan dengan defisit perilaku adaptif. Keterbatasan fungsi akan terlihat sebelum usia 18 tahun berupa keterbatasan komunikasi, merawat diri, keterampilan sosial, kemampuan bermasyarakat, pengarahan diri, kesehatan dan keamanan, akademik fungsional, istirahat, dan bekerja. ${ }^{1,2}$

Epidemiologi retardasi mental belum diketahui secara jelas, tetapi paling sering terjadi diantara anak usia sekolah, dengan angka yang lebih rendah pada periode pra sekolah atau post sekolah. ${ }^{2}$ Prevalensi di negara maju diperkirakan mencapai 0,5\%-2,5\%, insiden berkisar 3-4 kasus per 1000 anak, sedangkan di negara berkembang berkisar 4\%-6\%.3.-5 Prevalensi retardasi mental di Indonesia diperkirakan sebesar $12,15 \% .{ }^{6}$ Banyak penelitian melaporkan angka kejadian retardasi mental lebih banyak pada anak lakilaki dibandingkan perempuan. . $^{5,8}$

Etiologi retardasi mental dapat terjadi mulai dari fase pranatal, perinatal dan postnatal. Beberapa penulis secara terpisah menyebutkan lebih dari 1000 macam penyebab terjadinya retardasi mental, dan banyak diantaranya yang dapat dicegah. ${ }^{7,9,10}$ Salah satu defisiensi nutrisi yang diduga menjadi etiologi dari retardasi mental adalah defisiensi besi. Defisiensi besi akan menimbulkan defisit fungsi otak yang menetap sampai dewasa. ${ }^{11-14}$

Penelitian menunjukkan bahwa defisit fungsional otak dapat terjadi sebelum munculnya anemia defisiensi besi. Defisiensi besi yang terjadi pada masa perkembangan otak dapat mengakibatkan gangguan fungsi kognitif yang cenderung permanen. ${ }^{15,16}$

Defisiensi besi dapat disertai anemia atau tanpa anemia. Bila disertai anemia, kadar hemoglobin dan besi serum turun dibawah batas normal, sedangkan bila tanpa disertai anemia, terjadi penurunan cadangan besi dalam jaringan (feritin). ${ }^{13}$ Feritin merupakan protein yang memainkan peranan sangat penting dalam penyimpanan besi dalam tubuh. Feritin mewakili sekitar 20\% dari besi total dalam tubuh dan saat ini telah banyak digunakan sebagai indikator yang nyata status besi dalam tubuh dan diketahui bahwa kadar feritin serum lebih menggambarkan cadangan besi tubuh. $^{17}$

Penelitian ini bertujuan untuk mengetahui apakah terdapat perbedaan rerata kadar hemoglobin dan feritin berdasarkan tingkat inteligensia anak di SLB kota Padang.

\section{Metode}

Penelitian ini adalah penelitian cross sectional comparative study. Penelitian dilakukan di SLB Kota Padang. Pemeriksaan kadar hemoglobin dan feritin dilakukan di laboratorium Biomedik Fakultas Kedokteran Universitas Andalas.

Populasi penelitian adalah seluruh murid Sekolah Luar Biasa di Kota Padang, dan subjek penelitian adalah bagian dari populasi yang memenuhi kriteria inklusi dan eksklusi. Jumlah subjek penelitian adalah 60 orang, dibagi 3 kelompok, yaitu tidak RM, RM ringan, dan RM sedang-berat. Kriteria inklusi adalah siswa kelas C (tuna grahita), usia 6-18 tahun, dan bersedia mengikuti penelitian. Kriteria ekslusi adalah anak yang menderita penyakit keganasan, sedang mengalami infeksi, mengkonsumsi suplemen besi dalam 1 minggu terakhir, memiliki riwayat mendapat transfusi darah berulang, tes IQ tidak dapat dilakukan, dan memiliki kelainan kromosom/ wajah dismorfik.

Tingkat inteligensia dinilai menggunakan metode The Wechsler Intelligence Scale for Children-4 ${ }^{\text {th }}$ edition (WISC-IV) oleh Psikolog yang ditetapkan oleh peneliti. Anak dengan IQ $\geq 70$ diklasifikasi sebagai kelompok tidak RM, IQ 55-69 kelompok RM ringan, dan IQ < 55 kelompok RM sedang-berat. Pemeriksaan kadar hemoglobin menggunakan Sysmex XT 2000i dan kadar feritin diperiksa menggunakan metode Enzyme Linked Immunosorbent Assay (ELISA).

\section{Hasil}

Telah dilakukan penelitian terhadap 60 anak yang berasal dari 6 SLB di Kota Padang, berusia 6-18 tahun yang memenuhi kriteria inklusi dan eksklusi. Enam puluh anak dikelompokkan menjadi 3 kelompok berdasarkan tingkat inteligensia, yaitu 20 orang kelompok tidak RM, 20 kelompok RM ringan, dan 20 lainnya di kelompok RM sedang-berat. Berdasarkan jenis kelamin didapatkan 33 (55\%) subjek penelitian berjenis kelamin laki-laki dan 27 (45\%) perempuan. Rata-rata umur subjek penelitian adalah 12,96 tahun. Karakteristik subjek penelitian tiap kelompok tertera pada Tabel 1.

Berdasarkan karakteristik ditemukan adanya perbedaan usia yang bermakna antar ketiga kelompok. Didapatkan jumlah subjek dengan gizi kurang lebih banyak ditemukan pada kelompok RM sedang-berat 
Inggrit Anggraini dkk: Perbedaan rerata kadar hemoglobin dan feritin berdasarkan tingkat inteligensia

Tabel 1. Karakteristik subjek penelitian

\begin{tabular}{lccc}
\hline Karakteristik & $\begin{array}{c}\text { Tidak RM } \\
(\mathrm{n}=20)\end{array}$ & $\begin{array}{c}\text { RM ringan } \\
(\mathrm{n}=20)\end{array}$ & $\begin{array}{c}\text { RM sedang-berat } \\
(\mathrm{n}=20)\end{array}$ \\
\hline $\begin{array}{l}\text { Usia (tahun), } \\
\text { median (min-max) }\end{array}$ & 10,58 & 14,46 & 14,41 \\
Jenis kelamin, $\mathrm{n}(\%)$ & $(7,08-17,00)$ & $(10,83-17,08)$ & $(6,67-17,92)$ \\
$\quad$ Laki-laki & $14(70)$ & $10(50)$ & $9(45)$ \\
$\quad$ Perempuan & $6(30)$ & $10(50)$ & $11(55)$ \\
$\quad$ Status gizi, $\mathrm{n}(\%)$ & & & \\
$\quad$ Lebih & $5(25)$ & $8(40)$ & $3(15)$ \\
$\quad$ Baik & $10(50)$ & $6(30)$ & $8(40)$ \\
$\quad$ Kurang & $5(25)$ & $6(30)$ & $9(45)$ \\
Kadar Hb, $\mathrm{n}(\%)$ & & & \\
Anemia $(\mathrm{Hb}<11,5 \mathrm{~g} / \mathrm{dl})$ & $2(10)$ & $3(15)$ & $9(45)$ \\
Non anemia $(\mathrm{Hb} \geq 11,5 \mathrm{~g} / \mathrm{dl})$ & $18(90)$ & $17(85)$ & $11(55)$ \\
\hline
\end{tabular}

Tabel 2. Perbedaan kadar feritin berdasarkan tingkat inteligensia

\begin{tabular}{llll}
\hline Kelompok berdasarkan tingkat inteligensia & $\mathrm{n}$ & $\begin{array}{l}\text { Kadar feritin }(\mathrm{ng} / \mathrm{mL}) \\
\text { Median }(\min -\max )\end{array}$ & Nilai $\mathrm{p}$ \\
\hline Tidak RM & 20 & $63,03(20,29-484,37)$ & $<0,001^{*}$ \\
RM ringan & 20 & $66,8(18,19-163,22)$ & \\
RM sedang - berat & 20 & $12,24(2,59-39,87)$ & \\
\hline
\end{tabular}

* Uji Kruskal Wallis

Analisis post hoc Mann Whitney: tidak RM vs RM ringan $\mathrm{p}=0,808$, RM ringan vs $\mathrm{RM}$ sedang-berat $\mathrm{p}<0,001$, tidak $\mathrm{RM}$ vs $R M$ sedang-berat $\mathrm{p}<0,001$.

Data disajikan dalam median (minimum - maksimum)

dibandingkan kelompok tidak RM dan RM ringan. Subjek penelitian dengan gizi baik ditemukan lebih banyak pada kelompok tidak RM dibandingkan 2 kelompok lainnya. Penelitian ini juga mendapatkan $14(23,3 \%)$ subjek penelitian dengan kadar $\mathrm{Hb}$ yang dikategorikan sebagai anemia $(\mathrm{Hb}<11,5 \mathrm{~g} / \mathrm{dL})$, jumlah terbanyak (45\%) didapatkan pada kelompok RM sedang-berat.

Kadar feritin pada kelompok tidak RM dan RM ringanmemiliki beberapa nilai ekstrim, nilai ekstrim ini menunjukkan distribusi data yang tidak normal yang dibuktikan dengan uji Kolmogorov-Smirnov $(\mathrm{p}<0.05)$ sehingga data kadar feritin ditampilkan berupa median bukan rerata, dan untuk uji kemaknaan digunakan uji Kruskal-Wallis.

Tabel 2 menunjukkan nilai median kadar feritin pada kelompok tidak RM dan RM ringan lebih tinggi dibandingkan kelompok RM sedang-berat. Perbedaan kadar feritin ketiga kelompok tersebut bermakna secara statistik $(\mathrm{p}<0,05)$. Analisis post hoc Mann-Whitney menunjukkan terdapat perbedaan yang bermakna kadar feritin antara kelompok RM ringan dengan RM sedang-berat dan antara kelompok tidak RM dengan $\mathrm{RM}$ sedang-berat $(\mathrm{p}<0,001)$, akan tetapi tidak terdapat perbedaan yang bermakna kadar feritin antar kelompok tidak RM dengan RM ringan ( $p>0,05)$.

Kadar hemoglobin pada kelompok tidak RM dan RM ringanjuga memiliki nilai ekstrim. Akan tetapi, secara statistik data kadar hemoglobin ini terdistribusi normal yang dibuktikan dengan uji KolmogorovSmirnov $(p>0.05)$. Dengan demikian data kadar hemoglobin dapat ditampilkan berupa rerata, dan untuk uji kemaknaan digunakan uji analisis varian satu faktor.

Tabel 3 menunjukkan rerata kadar $\mathrm{Hb}$ pada kelompok tidak RM dan RM ringan lebih tinggi dibandingkan kelompok RM sedang-berat. Perbedaan rerata kadar $\mathrm{Hb}$ ketiga kelompok tersebut bermakna secara statistik $(\mathrm{p}<0,05)$. Analisis post hoc LSD menunjukkan terdapat perbedaan yang bermakna kadar 
Inggrit Anggraini dkk: Perbedaan rerata kadar hemoglobin dan feritin berdasarkan tingkat inteligensia

Tabel 3. Perbedaan kadar hemoglobin berdasarkan tingkat inteligensia

\begin{tabular}{lccc}
\hline Kelompok berdasarkan tingkat inteligensia & $\mathrm{n}$ & $\begin{array}{c}\text { Rerata kadar Hb }(\mathrm{g} / \mathrm{dL}) \\
\text { Mean } \pm \text { SD }\end{array}$ & Nilai $\mathrm{p}$ \\
\hline Tidak RM & 20 & $12,96 \pm 1,35$ & $0,037^{*}$ \\
RM ringan & 20 & $13,05 \pm 2,36$ & \\
RM sedang - berat & 20 & $11,55 \pm 2,19$ & \\
\hline
\end{tabular}

*Uji one way anova.

Analisis post hoc LSD: tidak RM vs $R M$ ringan $p=0,882$, $R M$ ringan vs $R M$ sedang-berat $p=0,022$, tidak $R M$ vs $R M$ sedangberat $\mathrm{p}=0,031$.

hemoglobin antara kelompok RM ringan dengan RM sedang-berat dan antara kelompok tidak RM dengan RM sedang-berat $(\mathrm{p}<0,05)$, akan tetapi tidak terdapat perbedaan yang bermakna kadar hemoglobin antara kelompok tidak RM dengan RM ringan ( $>0,05)$.

\section{Pembahasan}

Penelitian kami mendapatkan usia rata-rata subjek penelitian adalah 12,96 tahun. Penelitian Bragya dkk ${ }^{18}$ mendapatkan prevalensi retardasi mental terbanyak pada kelompok usia 9-12 tahun. Perbedaan usia yang bermakna juga didapatkan diantara ketiga kelompok berdasarkan tingkat inteligensia, terutama antara kelompok tidak RM dengan RM ringan dan antara kelompok tidak RM dengan RM sedang-berat.

Berdasarkan jenis kelamin dan status gizi, tidak ditemukan perbedaan yang bermakna antar ketiga kelompok subjek penelitian. Beberapa penelitian mendapatkan prevalensi retardasi mental lebih banyak pada anak laki-laki dibandingkan perempuan. ${ }^{18,19}$ Akan tetapi pada penelitian ini didapatkan jumlah yang hampir sama antara laki-laki dan perempuan pada ketiga kelompok subjek penelitian, hal ini dikarenakan jumlah subjek penelitian yang sedikit.

Status gizi kurang ditemukan pada ketiga kelompok dengan persentase pada kelompok RM sedang-berat lebih banyak dibandingkan dua kelompok lainnya, tetapi perbedaan ini tidak bermakna. Penelitian Abdallah dkk $^{20}$ di Mesir tahun 2007 dan Nogay ${ }^{21}$ di Turki tahun 2013 melaporkan prevalensi malnutrisi yang tinggi pada anak dengan retardasi mental.

Kejadian anemia terbanyak didapatkan pada kelompok RM sedang-berat. Anemia yang terjadi selama periode pertumbuhan dan perkembangan anak sangat berhubungan dengan derajat kesehatan dan perkembangan fisik yang buruk, retardasi mental ringan dan sedang, serta perkembangan dan pengontrolan motorik yang kurang sehingga menyebabkan penurunan prestasi akademik dan kapasitas kerja. Beberapa penelitian melaporkan bahwa anak anemia, terutama anemia defisiensi besi, akan mengalami penurunan fungsi kognitif secara bermakna dibandingkan kelompok non anemia. ${ }^{22-26}$

Penelitian mendapatkan perbedaan yang bermakna kadar feritin pada berbagai kelompok berdasarkan tingkat inteligensia. Kadar feritin rendah sebanding dengan retardasi mental berat yang ditandai dengan nilai IQ yang rendah. Uji statistik lanjutan (analisis post hoc) mendapatkan perbedaan kadar feritin yang bermakna antara kelompok RM ringan dengan RM sedang-berat dan antara kelompok tidak RM dengan RM sedang-berat.

Kadar feritin tidak terdistribusi normal dikarenakan adanya nilai ekstrim yang ditemukan pada sampel nomor 52. Kadar feritin pada sampel nomor 52 jauh lebih tinggi dibandingkan nilai rata-rata subjek penelitian lain dan melebihi nilai rujukan normal (15-300 ng/dL). Hal tersebut diduga disebabkan oleh obesitas yang ditemukan pada subjek, terjadi iron overload yang dapat menyebabkan kadar feritin serum tinggi. Penelitian oleh Moschonis $\mathrm{dkk}^{27}$ di Inggris melaporkan bahwa terdapat hubungan yang signifikan antara indeks massa tubuh dengan kadar feritin serum. Selain akibat adanya iron overload, kadar feritin yang tinggi juga disebabkan oleh proses inflamasi yang terjadi pada obesitas. ${ }^{28}$

Penelitian kami mendapatkan kadar feritin pada kelompok anak RM ringan lebih tinggi daripada kelompok anak tidak RM. Hal tersebut diduga disebabkan oleh distribusi data kadar feritin pada tiap kelompok yang tidak terdistribusi normal, dan adanya pengaruh status gizi antar kedua kelompok. Jumlah anak dengan status gizi lebih pada kelompok RM ringan lebih banyak dibandingkan dengan kelompok 
tidak RM, diduga pada keadaan gizi lebih terjadi kondisi iron overload.

Penelitian More $\mathrm{dkk}^{29}$ di India melaporkan terdapat penurunan IQ pada anak dengan defisiensi besi, baik disertai anemia atau tidak dibandingkan anak tanpa defisiensi besi. Penelitian serupa dilakukan oleh Gebril dkk ${ }^{30}$ di Kairo yang melaporkan penurunan kadar feritin pada kelompok anak dengan gangguan kognitif dibandingkan dengan kelompok control. Hal tersebut sesuai dengan hasil yang didapatkan pada penelitian kami bahwa terdapat perbedaan kadar feritin pada berbagai kelompok subjek penelitian berdasarkan tingkat inteligensia.

Defisiensi besi adalah suatu keadaan suplai besi yang tidak mampu menunjang sistem eritropoeisis normal, yang dikenal sebagai tahap iron deficient erythropoiesis atau iron limited erythropoiesis. Kondisi yang lebih berat jika disertai dengan penurunan kadar hemoglobin, disebut sebagai anemia defisiensi besi. Anemia defisiensi besi berhubungan dengan penampilan yang buruk dalam psikomotor dan skala perkembangan mental, dan tingkatan tingkah laku pada bayi, nilai yang rendah dalam uji fungsi kognitif pada anak prasekolah, pada anak usia sekolah nilai uji fungsi kognitif dan uji prestasi belajar juga rendah. ${ }^{31}$ Gejala anemia defisiensi besi tidak disebabkan karena penurunan hemoglobin semata, tetapi dipengaruhi juga oleh perubahan biokimia, seperti penurunan enzim yang mengikat zat besi, ko-enzim yang mengikat zat besi dalam siklus Krebs yang erat hubungannya dengan proses oksigenisasi sel termasuk sel jaringan otak. ${ }^{32}$

Defisiensi besi dapat menyebabkan terjadinya beberapa gangguan dalam perkembangan otak, diantaranya gangguan mielinisasi, dan gangguan regulasi neurotransmitter. Besi juga terlibat dalam sintesis neurotransmiter monoamine, seperti dopamin, serotonin (tryptophan hydroxylase) dan norepinefrin (tyrosine hydroxylase) yang terkait dengan proses kognitif dan emosional yang lebih tinggi, motivasi perilaku, afek positif dan fungsi motorik. Besi merupakan kofaktor pada ribonukleotida reduktase yang penting dalam mengatur fungsi dan metabolisme lemak serta energi otak sehingga defisiensi besi dapat menyebabkan penurunan aktivitas metabolik syaraf. ${ }^{32-34}$

Penelitian kami juga mendapatkan rerata kadar hemoglobin pada kelompok tidak RM dan RM ringan lebih tinggi dibandingkan kelompok RM sedangberat. Perbedaan rerata kadar hemoglobin antar ketiga kelompok tersebut bermakna secara statistik, dan pada analisis post hoc didapatkan perbedaan yang bermakna antara kelompok tidak RM dengan RM sedang-berat dan antara kelompok RM ringan dengan RM sedangberat.

Penurunan kadar hemoglobin merupakan tahapan akhir dari defisiensi besi yang dikategorikan sebagai anemia defisiensi besi (ADB). Keadaan ini terjadi bila besi yang menuju sumsum tulang sudah tidak lagi mencukupi sehingga menghambat produksi sel darah merah dan mengakibatkan kadar hemoglobin rendah. Penelitian yang dilakukan oleh Lozoff $\mathrm{dkk}^{35}$ di Costa Rika melaporkan bayi yang menderita $\mathrm{ADB}$ mempunyai nilai tes mental dan motorik skala Bayley yang rendah dibandingkan dengan bayi normal.

Anak yang mengalami defisiensi besi sejak masa bayi akan mengalami perkembangan psikomotor yang terlambat. Saat usia sekolah akan mengalami gangguan pada perkembangan bahasa, motorik, koordinasi, yang setara dengan penurunan IQ sebesar 5-10 poin. Mekanisme defisiensi besi dapat menyebabkan gangguan dan fungsi otak berhubungan dengan fungsi besi dalam sintesis neurotransmiter, mielinisasi, diferensiasi dan pertumbuhan neuron. ${ }^{32,34,36}$

Penelitian Yunirman ${ }^{37}$ di Padang melaporkan prevalensi defisiensi besi dan anemia defisiensi besi yang cukup tinggi, yaitu $16,5 \%$ dan $21,4 \%$. Penelitian ini menyimpulkan bahwa status besi berhubungan bermakna dengan prestasi belajar.

Keterbatasan penelitian kami antara lain, tidak dilakukan pemeriksaan kromosom, genetik ataupun faktor lingkungan seperti pola pengasuhan orangtua, stimulasi pada masa perkembangan otak, dan tingkat sosial ekonomi orangtua yang diketahui juga dapat memengaruhi tingkat inteligensia seorang anak. Dengan demikian tidak dapat ditentukan bahwa defisiensi besi adalah etiologi dari RM yang terjadi pada subjek penelitian. Defisiensi besi merupakan salah satu faktor yang menyebabkan tingkat inteligensia seorang anak rendah. Penelitian kami juga tidak menilai hubungan antara kadar hemoglobin dan kadar feritin secara bersamaan sehingga tidak dapat ditentukan faktor mana yang lebih mempengaruhi tingkat inteligensia anak.

\section{Kesimpulan}

Penelitian menyimpulkan kadar feritin pada anak RM sedang-berat lebih rendah dibandingkan anak tidak 
RM dan RM ringan. Terdapat perbedaan kadar feritin berdasarkan tingkat inteligensia anak di Sekolah Luar Biasa Kota Padang. Kejadian anemia lebih banyak ditemukan pada anak dengan RM sedang-berat dibandingkan anak tidak RM dan RM ringan, dan terdapat perbedaan kadar hemoglobin berdasarkan tingkat inteligensia.

Disarankan untuk penelitian lanjutan guna melihat hubungan penurunan kadar hemoglobin dan kadar feritin dengan keparahan RM, penelitian pemberian suplementasi besi, dan penilaian tingkat inteligensia setelah suplementasi. Dengan demikian, pemberian suplementasi besi pada anak RM dapat dipertimbangkan, terutama bila diketahui kemungkinan penyebab RM adalah defisiensi besi dan tidak ditemui adanya kelainan lain secara organik maupun kelainan genetik dan kromosom. Diharapkan hal tersebut dapat memperbaiki dan mencegah terjadinya gangguan kognitif yang lebih parah.

\section{Daftar pustaka}

1. Soetjiningsih. Retardasi mental. Dalam: Soetjiningsih, Ranuh G, penyunting. Tumbuh kembang anak. Edisi ke-2. Jakarta: EGC; 2013.h.511-26.

2. Yatchmink Y. Keterlambatan perkembangan: maturasi yang tertinggal hingga retardasi mental. Dalam: Bani PA, Limanjaya D, Anggraini D, Mahanani DA, Hartanto H, Mandera LI, penyunting. Buku Ajar Pediatri Rudolph. Edisi ke-20. Jakarta: EGC; 2006.h.136-9.

3. Saphiro BK, Batshaw ML. Mental retardation. Dalam: Behrman RE, Kliegman RM, Jenson HB, penyunting. Nelson textbook of pediatrics. Edisi ke-17. Philadelphia: Saunders; 2007.h.191-7.

4. Sularyo TS. Tumbuh kembang anak dengan minat khusus pada aspek pencegahan Tuna grahita. Disampaikan pada seminar sehari jangan sampai anakku tuna grahita, Jakarta, 21 November, 1992. 1992.

5. WHO. Primary prevention of mental neurological and psychosocial disorders. Geneva, WHO;1998:8-53.

6. Departemen Kesehatan. Laporan Riset Kesehatan Dasar (Riskesdas) 2010 Bidang Biomedis Jakarta: Badan Litbangkes, Depkes RI; 2010.

7. Lumbantobing SM. Anak dengan mental terbelakang. Jakarta: Balai Penerbit FKUI; 1997.

8. Ramelan W. Tuna grahita bawaan: latar belakang genetik dan deteksi dini pada orangtua. Disampaikan pada seminar sehari jangan sampai anakku tuna grahita, Jakarta, 21 November, 1992.
9. Armatas V. Mental retardation: definitions, etiology, epidemiology, and diagnosis. J Sport and Health Res 2009;1:112-22.

10. Sularyo TS, Kadim M. Retardasi mental. Sari Pediatri 2000;2:170-7.

11. 11. Chen MH, Su TP, Chen YS, Hsu JW, Huang KL, Chang WH, dkk. Association between psychiatric disorders and iron deficiency anemia among children and adolescents: a nationwide population-based study. BMC Psychiatry 2013;13:161.

12. Gratham-McGroger S, Ani C. A review of studies on the effect of iron deficiency on cognitive development in children. J Nutr 2001;131:649S-68S.

13. McCann JC, Ames BN. An overview of evidence for a causal relation between iron deficiency during development and deficits in cognitive or behavioral function. Am J Clin Nutr 2007;85:931-45.

14. Osendarp SJ, Murray-Kolb LE, Black MM. Case study on iron in mental development-in memory of John Beard (19472009). Nutr Rev 2010;68:48-52.

15. Soetjiningsih, Melati D. Pengaruh defisiensi besi terhadap tumbuh kembang anak Dalam: Soetjiningsih, Ranuh G, penyunting. Tumbuh kembang anak. Edisi ke-2. Jakarta: EGC; 2013.h.623-32.

16. Benton D. Micronutrient status, cognition and nehavioral problems in childhood. Eur J Nutr 2008;47:38-50.

17. Raspati H. Anemia defisiensi besi. Dalam: Permono HB, Sutaryo, Ugrasena IDG, Windiastuti E, Abdulsalam M, penyunting. Buku ajar hematologi onkologi anak. Jakarta: BP IDAI; 2006.h.30-4.

18. Bragya B, Ramakrishna A. Prevalence of mental retardation among children in Mangalore. Nitte University J Health Sci 2013;3:63-6.

19. Johnson CP, Walker WO. Mental retardation: management and prognosis. Pediatrics in Rev 2006;27:249-56.

20. Abdallah AM, El-Sherbeny SSA, Khairy S. Nutritional status of mentally disabled children in Egypt. Egypt J Hosp Med 2007;29:604-15.

21. Nogay NK. Nutritional status in mentally disabled children and adolescents: A study from Western Turkey. Pak J Med Sci 2013;29:614-8.

22. Hurtado EK, Claussen AH, Scott KG. Early childhood anemia and mild or moderate mental retardation. Am J Clin Nutr 1999;69:115-9.

23. Woldie H, Kebede Y, Tariku A. Factors associated with anemia among children aged 6-23 months attending growth monitoring at Tsitsika Health Center, Wag-Himra Zone, Northeast Ethiopia. J Nutr Metab 2015;2:1-9.

24. Shafir T, Angulo-Barroso R, Su J, Jacobson SW, Lozoff B. Iron 
deficiency anemia in infancy and reach and grasp development. Infant Behav Dev 2009;32:366-75.

25. Batra J, Sood A. Iron deficiency anaemia: effect on cognitive development in children: a review Indian J Clin Biochem 2005;20:119-25.

26. Jain M. Iron deficiency anaemia and cognition in school age girls: a comparison of iron and food supplementation strategies. Int J Nutr Agr Res 2014;1:55-62.

27. Moschonis G, Chrousos GP, Lionis C, Mougios V, Manios Y. Association of total body and visceral fat mass with iron deficiency in preadolescents: the Healthy Growth Study. Brit J Nutr 2012;108:1-8.

28. Zafon C, Lecube A, Simó R. Iron in obesity. An ancient micronutrient for a modern disease. Obesity Rev. 2010;11:322-8.

29. More S, Shivkumar VB, Gangane N, Shende S. Effects of Iron Deficiency on Cognitive Function in School Going Adolescent Females in Rural Area of Central India. Hindawi Pub Corp 2013;2013:1-5.

30. Gebril OH, Abdelraouf ER, Hashish AF. A study of zinc, copper and iron parameters in children with cognitive impairment. Med Res J 2014;13:40-4.

31. Chauhan U, Golhar S, Dahake P. Correlation between iron deficiency anemia and cognitive achievement in school aged children. Annals of Int Med Den Res 2016;2:178-80.

32. Georgieff MK. Iron in the brain: its role in development and Injury. Neo Rev 2006;7:344-52.

33. Thomas DG, Grant SL, Aubuchon-Endsley NL. The role of iron in neurocognitive development. Dev Neuropsychol 2009;34:196-222.

34. Lozoff B, Georgieff MK. Iron deficiency and brain development. Semin Pediatr Neurol 2006;13:158-65.

35. Lozoff B, Jimenez F, Hagen J, Mollen E, Wolf AW. Poorer behavioral and developmental outcome more than 10 years after treatment for iron deficiency in infancy. Pediatrics 2000;105:51-5.

36. Lena H. Iron deficiency and cognition. Scand J Nutr 2003;47:152-6.

37. Yunirman Y. Hubungan status besi dengan prestasi belajar murid kelas V SD di Kecamatan Koto Tangah Kota Padang, tesis. Fakultas Kedokteran Universitas Andalas, 2003. 